\title{
Dates, Place Names, Currencies, Translations
}

At the time the Ottoman bureaucracy used the lunar Hicri and the Rumi calendars; so did Bulgaria's Muslims in the sources they produced. Bulgaria used the Julian calendar. For simplicity, all dates in this book have been converted to the Gregorian calendar.

For places located in Bulgaria, this book uses the Bulgarian version of names common at the time: for example, Kurtbunar instead of Tervel. For places in the Ottoman Empire, it uses the Ottoman names: for example, Edirne rather than Adrianople or Odrin.

The national currency of Bulgaria—lev (sg.), leva (pl.) — was roughly equal to the French frank during the period under consideration. Contemporary sources occasionally used the two currencies interchangeably.

All translations are the author's unless otherwise specified. 